\title{
Collateral damage: Exchange controls and international trade
}

\author{
Shang-Jin Wei ${ }^{a, b, *}$, Zhiwei Zhang ${ }^{b}$

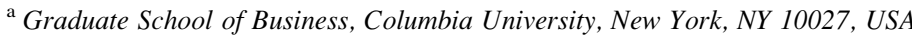 \\ ${ }^{\mathrm{b}}$ Research Department, International Monetary Fund, 700 19th Street, N.W., \\ Washington, DC 20431, USA
}

\begin{abstract}
While new conventional wisdom warns that developing countries should be aware of the risks of premature capital account liberalization, the costs of not removing exchange controls have received much less attention. This paper investigates the negative effects of exchange controls on trade. To minimize evasion of controls, countries often intensify inspections at the border and increase documentation requirements. Thus, the cost of conducting trade rises. The paper finds that a one standard deviation increase in the controls on trade payment has the same negative effect on trade as an increase in tariff by about 14 percentage points. A one standard deviation increase in the controls on FX transactions reduces trade by the same amount as a rise in tariff by 11 percentage points. Therefore, the collateral damage in terms of foregone trade is sizable.
\end{abstract}

(C) 2007 Elsevier Ltd. All rights reserved.

JEL codes: F1; F2

Keywords: Capital controls; Capital account liberalization; Trade flows; Non-tariff barriers

\footnotetext{
* Corresponding author. Research Department, International Monetary Fund, 700 19th Street, N.W., Washington, DC 20431, USA. Tel.: +1 202623 5980; fax: +1 2025897271.

E-mail address: swei@imf.org (S.-J. Wei).
} 


\section{Introduction}

Since the emerging market crisis of the 1990s, a new conventional wisdom has emerged that developing countries should be alert to the adverse effects of premature capital account liberalizations (see Rodrik, 1998; Stiglitz, 2002; and other papers reviewed by Prasad et al., 2003). In comparison, the costs of not removing exchange controls have received much less attention in empirical research. A notable exception is a study by Forbes (in press) which estimated the effect of Chile's capital controls ("encaje") in the early 1990s on the cost of borrowing faced by its medium-sized publicly-listed firms.

In this paper, we estimate another possible collateral damage of exchange controls, namely their effects on international trade, and compare them to those of tariff and other non-tariff barriers (NTBs). The study was motivated in part by a conversation we had some years ago with the chief of the national foreign exchange control administration of a country which shall remain anonymous. As the country was on a fixed exchange rate regime (and any change in the regime was to be decided by the government cabinet rather than by the foreign exchange control administration) and by then had permitted current account convertibility of its currency, we asked the chief why his bureau needed to have a large staff nationally. The response was that it was common for firms and individuals to try to circumvent capital account restrictions by mis-invoicing imports, exports or both, and his staff had to implement various inspections to minimize such leakages. It dawned on us that attempts to enforce exchange controls have most likely raised the cost for firms to engage in exports and imports. How much extra cost these controls effectively impose on international trade is the subject of the current research reported here.

The paper combines three unique panel data sets: (a) a detailed description (192 indicators) of the exchange controls for up to 184 countries since 1996 in the IMF's Annual Report on Exchange Arrangements and Exchange Restrictions (AREAER) database; (b) importer-partner country-specific tariff rates from the UNCTAD's Trade Analysis and Information System (TRAIN), retrieved via the World Integrated Trade Solution (WITS) at the IMF; and (c) a rating of the extent of non-tariff barriers from the IMF's Trade Restrictiveness Index database. These data are then combined with bilateral trade data from the IMF's Direction of Trade database as well as additional control variables from other sources. The econometric specification is grounded in the theory of trade volume, including recent development in Anderson and Van Wincoop (2003) and Helpman et al. (2005).

To our knowledge, Tamirisa (1999) was the first and the only other paper that studied the effect of exchange restrictions on trade. Due to data limitation, her sample covers only one year (1996) and 40 countries. Perhaps more importantly, the estimation was based on a misspecified model as it did not incorporate separate importer and exporter fixed effects which are required of by economic theory. For example, Anderson and Van Wincoop (2003) show that the omission of these fixed effects has artificially generated the so-called "border effect" in trade volume. Subramanian and Wei (2007) show that the inclusion of the fixed effects can reverse Rose's (2004) conclusion on the ineffectiveness of the WTO in promoting trade. It is therefore important to specify the trade volume equation in a way that is consistent with economic theories.

Due to the comprehensive descriptions of the exchange controls in the AREAER database since 1996, we are able to construct separate indicators for (a) controls on proceeds from exports and payments for imports, (b) controls on capital transactions, and (c) controls on foreign exchange (FX) transactions and other items not specific to goods trade or capital transactions. Note that the phrases "capital controls" and "exchange controls" are used interchangeably in 
this paper as they refer to all three categories of controls, not just those on capital transactions. A narrower definition of "capital controls" may include only controls on capital transactions plus controls on most FX transactions. According to Johnson et al. (2006), several capital control measures adopted in Malaysia during the Asian financial crisis were not targeted at specific capital transactions, but at all FX transactions.

To preview the main findings, we will report economically and statistically significant evidence of negative effects of exchange controls on trade. In particular, a one standard deviation increase in the controls on export receipts and import payments is found to have the same negative effect on trade as an increase in tariff by 8.7-13.9 percentage points, depending on the model specifications. A one standard deviation increase in the controls on FX transactions reduces trade by the same amount as a rise in tariff by $10.8-11.3$ percentage points. When a case study of the emerging markets during 1996-1999 is examined, we find that those countries with greater increases in the controls on capital transactions also experienced greater falls in their trade (after taking into account their output contractions). To summarize, exchange controls effectively work as a form of non-tariff barriers to trade even though they have not been typically characterized as NTBs in the literature. We conclude that the collateral damage of imposing exchange controls in terms of foregone trade is sizable.

The paper is arranged as follows. Section 2 describes some basic patterns regarding the exchange controls across countries and over time. Section 3 presents the statistical analysis. Section 4 concludes.

\section{Exchange controls: some basic patterns}

The IMF's AREAER database uses up to 192 indicators - listed in an Appendix - to track the exchange controls for individual member countries from 1996. We divide these controls into three broad categories and construct an index for each category. Each index ranges from 0 to 1 , reflecting the proportion of the indicators in each category that has controls in place. The three categories are:

a) Controls on payments for imports and proceeds from exports. They cover 35 controls that explicitly target transactions related to international trade, including requirements for a foreign exchange budget for imports, and documentation and financing requirements for import payments and export proceeds.

b) Controls on capital transactions. They cover 86 controls on transactions of capital and money market instruments, derivatives, FDI, credit operations, real estates, and personal finance. They also include controls on the operation of institutional investors and commercial banks.

c) Controls on FX transactions and other items that are not exclusively on trade or capital transactions. They include exchange taxes and subsidies, ban on currency derivative

Table 1a

Summary statistics for restriction indices

\begin{tabular}{llllll}
\hline & Mean & Median & Std. dev. & Min & Max \\
\hline Trade payments & 0.26 & 0.23 & 0.19 & 0 & 1 \\
Capital transactions & 0.46 & 0.45 & 0.31 & 0 & 1 \\
FX transactions & 0.32 & 0.27 & 0.24 & 0 & 0.91 \\
\hline
\end{tabular}




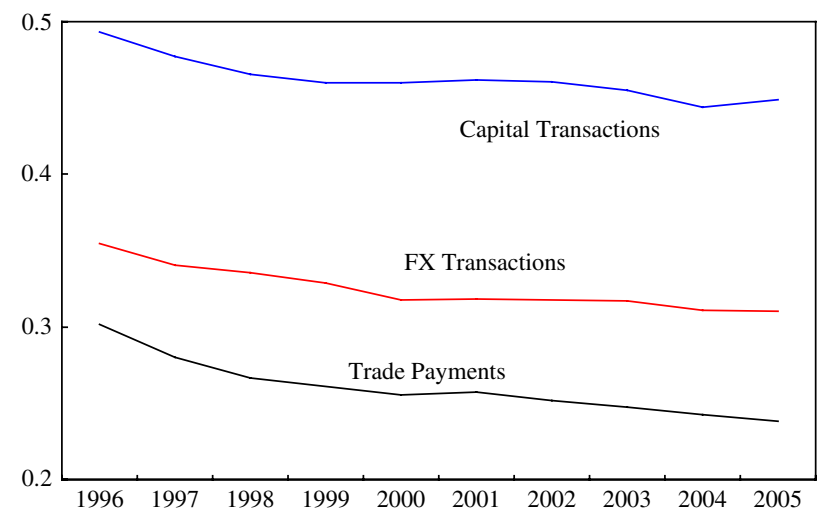

Fig. 1. Evolutions of restriction indices (average across countries, 1996-2005).

trading, controls on bank accounts, currency requirements for pricing and settlements, current transfers and invisible transactions, and trade in gold and banknotes.

On average, as Table 1a and Fig. 1 indicate, countries tend to have more controls on capital transactions and foreign exchange transactions than on trade payments. Furthermore, all three indices show a moderate decline during the period from 1996 to 2005. The average index value for controls on capital transactions dropped from 0.49 in 1996 to 0.45 in 2005 . The index for controls on trade payments, and that for FX transactions, also declined from 0.30 to 0.24 , and from 0.35 to 0.31 , respectively, during the same period. Countries with more controls in one category are also likely to have more controls in the other categories, as indicated by the pair-wise correlations of about $0.67-0.76$ (Table 1b).

The average values of the indices mask substantial cross-country heterogeneity and time-series variations for many countries. To illustrate this point, Fig. 2 presents the patterns for three developing countries on two continents (Brazil, Chile, and Malaysia) and one OECD member country (Greece). Each has experienced substantial changes in the controls during the sample period.

Brazil first tightened controls on capital transactions and foreign exchange transactions in the 1990s, but then liberalized dramatically in 2002. Its controls on trade payments fluctuate a bit, with a generally downward trend. Chile's story is equally dramatic. While it started off with a fairly restrictive regime on capital transactions, with a value of 0.75 for the relevant index in 1996, major reforms in 2001/2002 removed more than half of the controls,

Table 1b

Correlations of the control indices, tariff, and NTB index

\begin{tabular}{llllll}
\hline & Trade payments & Capital transactions & FX transactions & Tariff & NTB index \\
\hline Trade payments & 1.00 & 0.62 & 0.70 & 0.44 & 0.21 \\
Capital transactions & 0.62 & 1.00 & 0.72 & 0.46 & 0.03 \\
FX transactions & 0.70 & 0.72 & 1.00 & 0.54 & 0.05 \\
Tariff & 0.44 & 0.46 & 0.54 & 1.00 & 0.14 \\
NTB index & 0.21 & 0.03 & 0.05 & 0.14 & 1.00 \\
\hline
\end{tabular}



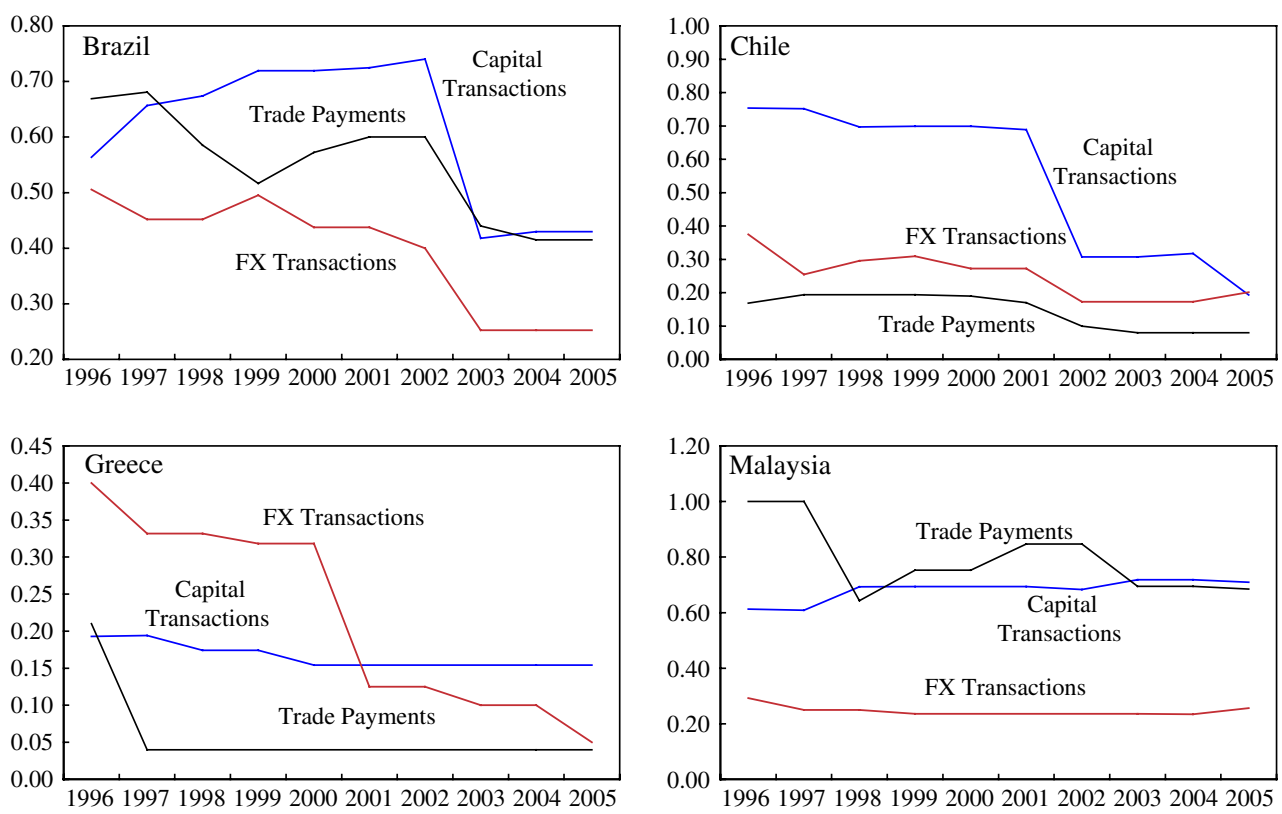

Fig. 2. Control indices in selected countries. Source: IMF Annual Report on exchange arrangements and exchange restrictions, and staff estimates.

including those on transactions of equity, bonds, real estate, and direct investment. This results in a decline in the index value to 0.19 by 2005. During the same period, Chile also removed some controls on trade payments, though there were relatively few of them to begin with.

Greece exhibits two major episodes of liberalization of the controls on FX transactions in 1997 and 2001 with modest reforms in other years. Virtually all controls on FX transactions had been removed by 2005. Controls on capital transactions loosened more gradually over time. While Malaysia reduced its controls on trade payments in the mid-1990s, it tightened its controls on capital transactions during the Asian financial crisis, through introducing new controls on the transactions of bonds, derivatives, real estate, and other debt instruments by nonresidents. The index for controls on capital transactions jumped from 0.61 in 1997 to 0.69 in 1998 , climbing further to 0.75 by 2004 . Some of these controls have been removed or loosened since 2001, but these changes apparently are not fully reflected in the database.

The variations across countries and over time will prove helpful in identifying the effects of exchange controls on international trade in empirical specifications with country and year fixed effects. It is important to point out, however, that as measures of exchange controls, these indices are not perfect either. First, the AREAER database only reflects the presence or absence of specific exchange restrictions on the book, but not the degree of enforcement on the ground. Second, in spite of up to 192 indicators to describe the controls, for any given indicator, the intensity of the controls is not well captured by the database. In light of these shortcomings, the statistical findings should be interpreted with caution. Nonetheless, the AREAER database may be the only source that covers the near universe of the countries and codes the controls in a consistent way across countries. 


\section{Statistical analysis}

We now turn to the regression analysis. Starting with an explanation of the benchmark specification and the data on tariffs and non-tariff barriers, we move to reporting some basic results and computing the tariff equivalents of the exchange controls. We then discuss a number of extensions including a case study of the emerging markets' experience during the financial crisis episode of the late 1990s.

\subsection{Specification}

An augmented gravity model is utilized to study the effect of exchange controls on trade. The gravity model is one of the most successful empirical models in economics, as it is capable of explaining a large fraction of the variations in observed volumes of international trade, with adjusted $R^{2}$ of $70 \%$ or higher. It has also been applied to analyze the effects of a variety of policies on trade. ${ }^{1}$ The specification used in this paper incorporates recent theoretical insights from Anderson and Van Wincoop (2003) and Helpman et al. (2005). It allows us to compute a tariffequivalent measure of the exchange controls in terms of their effects on trade. To be precise, the benchmark model is specified in the following form:

$$
\begin{aligned}
Y_{i, j, t}= & \alpha_{1} \mathrm{IMP}_{i}+\alpha_{2} \mathrm{EXP}_{j}+\alpha_{3} \operatorname{Year}_{t}+X_{i, j, t} \beta+\text { Restriction Indices }_{i, t} \gamma+\delta \operatorname{Tariff}_{i, j, t} \\
& +\eta \mathrm{NTB}_{i, t}+\epsilon_{i, j, t} .
\end{aligned}
$$

The dependent variable $Y_{i, j, t}$ is country $i$ 's $\log$ imports from country $j$ in year $t$. The key variables of interests are the three restriction indices, the tariff rates, and the NTB index. In addition, $\mathrm{IMP}_{i, j}, \mathrm{EXP}_{i, j}$, and $\mathrm{Year}_{t}$ are the importer, exporter, and year fixed effects, respectively. $X_{i, j, t}$ is a list of variables that previous studies have found significant in explaining the volume of trade, including log GDP, great circle distance between $i$ and $j$, dummies for common language, colonial links, and shared borders. Following Helpman et al. (2005), we also include a Mills ratio and another HMR variable to correct for the non-random presence of zero trade and intra-sector firm heterogeneity.

The importer and exporter fixed effects are meant to capture the "remoteness" terms in Wei (1996) or the "multilateral resistance" terms in Anderson and Van Wincoop (2003). Note, however, that we are not able to include time-varying country fixed effects as that will render it impossible to identify the effects of exchange controls (which are part of the time-varying country-specific factors). As an extension, we will use a specification that includes time-varying import price index for exporters and importers separately. In addition, we will examine a specification that includes (non-time-varying) country-pair fixed effects which are also more general than the importer-exporter fixed effects.

\subsection{Data}

The sample includes 142 countries for which information about trade flows, tariff rates, the non-tariff barrier index, and exchange controls are available. A list of these countries is

\footnotetext{
${ }^{1}$ See Frankel and Wei (1994) and Frankel et al. (1997) on free trade areas, Rose (2004) and Subramanian and Wei (2003) on the WTO, among others.
} 
provided in Appendix 2. As will be clear, this paper concludes that many of the exchange controls are effectively non-tariff barriers in terms of their effects on trade. However, conventionally measured NTBs in the literature do not usually include exchange controls. For comparison, we adopt a separate measure of the NTBs in the traditional sense of the phrase based on the IMF's Trade Restrictiveness Index database. The index takes a value of 1, 2 or 3, depending on the coverage ratio or other dimensions of non-tariff barriers to trade. According to the IMF (2005), the index takes the value of 1 if NTBs are absent or minor in a country (i.e., less than $1 \%$ of production or trade is subject to NTBs). A rating of 2 implies that NTBs are significant, applied to at least one important sector, and affecting up to $25 \%$ of production or trade. A rating of 3 means that NTBs are relevant for many sectors or an entire stages of production, affecting more than $25 \%$ of production or trade. In the IMF database, the NTB index takes the value of 2 for a large number of country-years. So a rise in the index's value from 1 to 2 , or from 2 to 3 , represents a fairly significant increase in the extent of non-tariff barriers.

The tariff rate for a given country pair in a given year is a simple average of the applicable tariff rates across all tariff lines for that importer and that specific trading partner (so that members of a free trade area would face different tariffs from non-members).

\subsection{Benchmark results}

We now turn to the regression results which are reported in Table 2 . The first three regressions include the three exchange control indices one by one. The controls on trade payments have a strong adverse effect on trade. The point estimate for $\gamma$ is -0.57 , and is highly significant. The coefficient for controls on capital transactions is negative but insignificant. The estimate for controls on FX transactions is -0.31 and significant at the $10 \%$ level. Note that all standard errors are clustered by importer-exporter country pairs. ${ }^{2}$

Most other regressors are significant and with intuitive signs. In particular, the estimate for tariff rates is -0.71 and highly significant, which implies that increasing tariff by 10 percentage points is associated with a $7.1 \%$ reduction in trade. The estimate for NTB index is -0.22 and also highly significant. This implies that a one-step increase in the NTB index would have equivalent effect on trade as a 30 percentage points increase in tariff rates. GDP, distance, dummies for border, colonial ties, and common language are all significant and consistent with the previous literature. Trade between two WTO members is about $38 \%$ higher, while the trade between a WTO member and a non-member is about $17 \%$ lower.

Column 4 in Table 2 provides estimates when all three restriction indices are included in one regression. The point estimate for the controls on trade payments remains significant at -0.54 . Controls on capital transactions are still insignificant. The coefficient for FX transactions became insignificant, although it still shows a negative sign. Estimates for all other variables are virtually unchanged.

The model allows us to conduct a tariff equivalent calculation for the exchange controls. Take column 4 in Table 2 as an example. As the standard deviation of the controls on trade

\footnotetext{
${ }^{2}$ When the standard errors are clustered by importers rather than importer-exporter pairs, some standard gravity variables such as log of importer's GDP as well as the three exchange controls lose statistical significance. This suggests that clustering by importers may be an overkill if one's prior is that the standard gravity variables should be significant. For this reason, we choose to cluster by importer-exporter pairs. Note that the importer fixed effects already take into account an important source of common variations across variables for any given importer.
} 
Table 2

Benchmark regressions

\begin{tabular}{|c|c|c|c|c|c|c|c|c|}
\hline \multicolumn{9}{|c|}{ Dependent variable: $\log$ bilateral imports } \\
\hline & 1 & 2 & 3 & 4 & 5 & 6 & 7 & 8 \\
\hline Controls on trade payments & $-0.567(0.153)$ & & & $-0.537(0.159)$ & $-0.434(0.103)$ & & & $-0.367(0.109)$ \\
\hline $\begin{array}{l}\text { Controls on capital } \\
\text { transactions }\end{array}$ & & $-0.068(0.107)$ & & $0.032(0.110)$ & & $-0.018(0.069)$ & & $0.087(0.072)$ \\
\hline $\begin{array}{c}\text { Controls on FX } \\
\text { transactions }\end{array}$ & & & $-0.314(0.171)$ & $-0.152(0.180)$ & & & $-0.438(0.116)$ & $-0.353(0.124)$ \\
\hline Tariff & $-0.713(0.182)$ & $-0.724(0.182)$ & $-0.725(0.182)$ & $-0.717(0.182)$ & $-0.774(0.107)$ & $-0.784(0.107)$ & $-0.801(0.107)$ & $-0.784(0.107)$ \\
\hline Non-tariff barrier index & $-0.213(0.049)$ & $-0.226(0.048)$ & $-0.221(0.048)$ & $-0.212(0.048)$ & $-0.181(0.034)$ & $-0.189(0.034)$ & $-0.186(0.034)$ & $-0.178(0.034)$ \\
\hline Log GDP importer & $0.728(0.167)$ & $0.714(0.168)$ & $0.671(0.168)$ & $0.706(0.168)$ & $1.231(0.099)$ & $1.216(0.099)$ & $1.144(0.101)$ & $1.169(0.101)$ \\
\hline Log GDP exporter & $0.48(0.165)$ & $0.477(0.165)$ & $0.475(0.165)$ & $0.479(0.165)$ & $0.865(0.091)$ & $0.858(0.091)$ & $0.845(0.091)$ & $0.852(0.092)$ \\
\hline Log distance & $-1.499(0.026)$ & $-1.499(0.026)$ & $-1.499(0.026)$ & $-1.498(0.026)$ & & & & \\
\hline Border & $0.666(0.165)$ & $0.668(0.165)$ & $0.666(0.165)$ & $0.668(0.165)$ & & & & \\
\hline Ever colony & $1.007(0.097)$ & $1.008(0.097)$ & $1.008(0.097)$ & $1.008(0.097)$ & & & & \\
\hline Common language & $0.603(0.049)$ & $0.603(0.049)$ & $0.603(0.049)$ & $0.603(0.049)$ & & & & \\
\hline $\begin{array}{l}\text { Importer WTO member, } \\
\text { exporter not }\end{array}$ & $-0.166(0.089)$ & $-0.184(0.089)$ & $-0.174(0.089)$ & $-0.162(0.089)$ & $0.25(0.055)$ & $0.237(0.055)$ & $0.252(0.055)$ & $0.258(0.056)$ \\
\hline $\begin{array}{l}\text { Both countries WTO } \\
\text { members }\end{array}$ & $0.385(0.065)$ & $0.367(0.066)$ & $0.376(0.066)$ & $0.388(0.066)$ & $0.358(0.049)$ & $0.343(0.049)$ & $0.352(0.049)$ & $0.361(0.049)$ \\
\hline $\begin{array}{l}\text { Mills ratio for } \\
\text { non-zero trade }\end{array}$ & $5.701(0.495)$ & $5.674(0.499)$ & $5.699(0.496)$ & $5.678(0.499)$ & $-0.992(1.240)$ & $-0.979(1.241)$ & $-1.028(1.240)$ & $-1.03(1.240)$ \\
\hline $\begin{array}{l}\text { HMR predicted } \\
\text { probability } \\
\text { of non-zero trade }\end{array}$ & $10.27(0.791)$ & $10.227(0.796)$ & $10.267(0.791)$ & $10.234(0.795)$ & $-0.556(1.958)$ & $-0.492(1.958)$ & $-0.427(1.958)$ & $-0.495(1.958)$ \\
\hline Importer fixed effect & Yes & Yes & Yes & Yes & No & No & No & No \\
\hline Exporter fixed effect & Yes & Yes & Yes & Yes & No & No & No & No \\
\hline Country-pair fixed effect & No & No & No & No & Yes & Yes & Yes & Yes \\
\hline Year fixed effect & Yes & Yes & Yes & Yes & Yes & Yes & Yes & Yes \\
\hline Observations & 58098 & 58065 & 58098 & 58065 & 58098 & 58065 & 58098 & 58065 \\
\hline$R^{2}$ & 0.76 & 0.76 & 0.76 & 0.76 & 0.02 & 0.02 & 0.02 & 0.02 \\
\hline
\end{tabular}


payments is 0.19 , an increase in this type of controls by one standard deviation would have the same negative effect on trade as raising tariff rate by $100 \times 0.19 \times 0.54 / 0.72=14.3$ percentage points.

We also implement a set of regressions with country-pair fixed effects, which are more general than importer-exporter fixed effects. The results are shown in columns 5-8 of Table 2 . When the restriction indices are included one by one, the results are similar qualitatively as before: the coefficients on both controls on trade payments and FX transactions are negative and significant, while that on controls on capital transactions remains insignificant. When all three indices are included together, the estimate for controls on trade payments becomes -0.37 and significant, while controls on FX transactions increases to -0.35 . The coefficient for tariff rates is now -0.78 and significant. These estimates imply that an increase in the exchange controls by one standard deviation ( 0.19 and 0.24 , respectively) is equal to $100 \times 0.19 \times 0.37 / 0.78=9.0$ percentage points increase in tariff rate for controls on trade payments, and $100 \times 0.24 \times 0.35$ / $0.78=10.8$ percentage points increase in tariff rate for controls on FX transactions.

\subsection{Alternative specification with time-varying price indices}

As we are not able to include time-varying importer fixed effects, we use time-varying import price indices for both importers and exporters from the World Economic Outlook database to proxy for the time-varying country-specific price factors. Import price indices are better than CPI indices because the theory (Anderson and Van Wincoop, 2003) suggests an index of tradable goods prices, but CPI would be dominated by nontradable components.

The results from this alternative specification, reported in Table 3, are mostly consistent with the benchmark case. When the restriction indices are included individually, all three types of controls have negative and significant coefficients. When they are included collectively, both controls on trade payments and those on FX transactions remain significant, while controls on capital transactions become insignificant. The point estimate for controls on trade payments is -0.49 , implying slightly larger effect than those in the benchmark regressions. The coefficients for tariff rates are estimated to be about -0.72 , close to those in the benchmark regressions. These estimates imply a tariff equivalent of 13 percentage points for a one standard deviation increase in the controls on trade payments, and 14 percentage points for a similar increase in the controls on FX transactions. In the last column of Table 3 (non-time-varying), country-pair fixed effects as well as time-varying imported goods price indices for exporters and importers are included in the same regression. With this specification, the controls on trade payments still have a negative and significant coefficient, though the coefficient on controls on foreign exchange transactions becomes negative and insignificant. For some reasons, the coefficient on controls on capital transactions becomes positive and significant. It is worth noting that the last column represents a fairly demanding specification with many more parameters to be estimated relative to the regressions in columns $1-4$ of Table 3 .

\subsection{Developing countries}

There are reasons to think that the same exchange controls may have a smaller negative effect on trade for developing countries than for developed countries. For example, bribery and corruption at the customs may be more prevalent in developing countries so that a given control is easier to be evaded. On the other hand, trading firms in developing countries may have a harder time than their counterparts in developed countries in obtaining trade credit to 
Table 3

Adding time-varying price indices

\begin{tabular}{|c|c|c|c|c|c|}
\hline \multicolumn{6}{|c|}{ Dependent variable: log bilateral imports } \\
\hline & 1 & 2 & 3 & 4 & 5 \\
\hline $\begin{array}{l}\text { Controls on trade } \\
\text { payments }\end{array}$ & $-0.633(0.154)$ & & & $-0.494(0.161)$ & $-0.430(0.142)$ \\
\hline $\begin{array}{l}\text { Controls on capital } \\
\text { transactions }\end{array}$ & & $-0.187(0.102)$ & & $-0.033(0.108)$ & $-0.195(0.150)$ \\
\hline $\begin{array}{l}\text { Controls on FX } \\
\text { transactions }\end{array}$ & & & $-0.608(0.162)$ & $-0.438(0.174)$ & $0.343(0.111)$ \\
\hline Tariff & $-0.708(0.181)$ & $-0.726(0.182)$ & $-0.728(0.182)$ & $-0.721(0.182)$ & $-0.810(0.111)$ \\
\hline $\begin{array}{l}\text { Non-tariff barrier } \\
\text { index }\end{array}$ & $-0.177(0.047)$ & $-0.197(0.047)$ & $-0.178(0.047)$ & $-0.17(0.047)$ & $-0.102(0.042)$ \\
\hline $\begin{array}{l}\text { Log GDP } \\
\text { importer }\end{array}$ & $0.916(0.037)$ & $0.912(0.037)$ & $0.881(0.037)$ & $0.891(0.037)$ & $1.669(0.144)$ \\
\hline $\begin{array}{l}\text { Log GDP } \\
\quad \text { exporter }\end{array}$ & $1.192(0.046)$ & $1.193(0.046)$ & $1.19(0.046)$ & $1.194(0.046)$ & $0.843(0.099)$ \\
\hline Log distance & $-1.502(0.026)$ & $-1.501(0.026)$ & $-1.502(0.026)$ & $-1.501(0.026)$ & \\
\hline Border & $0.651(0.164)$ & $0.652(0.164)$ & $0.651(0.164)$ & $0.653(0.164)$ & \\
\hline Ever colony & $1.008(0.097)$ & $1.009(0.097)$ & $1.009(0.097)$ & $1.009(0.097)$ & \\
\hline Common language & $0.604(0.049)$ & $0.604(0.049)$ & $0.603(0.049)$ & $0.604(0.049)$ & \\
\hline $\begin{array}{l}\text { Importer WTO } \\
\text { member, exporter } \\
\text { not }\end{array}$ & $-0.122(0.087)$ & $-0.141(0.088)$ & $-0.134(0.087)$ & $-0.12(0.087)$ & $0.217(0.078)$ \\
\hline $\begin{array}{l}\text { Both countries } \\
\text { WTO member }\end{array}$ & $0.37(0.064)$ & $0.351(0.064)$ & $0.356(0.064)$ & $0.37(0.064)$ & $0.353(0.072)$ \\
\hline $\begin{array}{l}\text { HMR predicted } \\
\text { probability of } \\
\text { non-zero trade }\end{array}$ & $10.522(0.797)$ & $10.481(0.802)$ & $10.521(0.797)$ & $10.486(0.802)$ & 0.862 (1.976) \\
\hline $\begin{array}{l}\text { Mills ratio for } \\
\text { non-zero trade }\end{array}$ & $5.839(0.499)$ & $5.813(0.503)$ & $5.837(0.500)$ & $5.815(0.503)$ & $-0.046(1.264)$ \\
\hline $\begin{array}{l}\text { Import price index, } \\
\text { importing country }\end{array}$ & Yes & Yes & Yes & Yes & Yes \\
\hline $\begin{array}{l}\text { Import price index, } \\
\text { exporting country }\end{array}$ & Yes & Yes & Yes & Yes & Yes \\
\hline $\begin{array}{l}\text { Country-pair fixed } \\
\text { effect }\end{array}$ & No & No & No & No & Yes \\
\hline Year fixed effect & Yes & Yes & Yes & Yes & Yes \\
\hline Observations & 56711 & 56678 & 56711 & 56678 & 56678 \\
\hline$R^{2}$ & 0.76 & 0.76 & 0.76 & 0.76 & 0.03 \\
\hline
\end{tabular}

Note: Robust standard errors, clustered by importers, are in parentheses. $R^{2}$ in the last column does not include the variations explained by the country-pair fixed effects.

overcome the exchange controls. In this case, the same exchange controls may have a larger negative effect. This discussion suggests that it may be useful to check if the results for developing countries are different for the whole sample.

Table 4 focuses on a sub-sample in which both importers and exporters are developing countries. The results are consistent with (though somewhat weaker than) the benchmark regressions. Columns 1-4 are regressions with importer, exporter, and year fixed effects. When three control measures are included separately in regressions, all of them have the expected negative signs with the coefficients on controls on trade payments and FX transactions being significant. When included jointly, all three controls have negative coefficients but only 
Table 4

Developing countries

\begin{tabular}{|c|c|c|c|c|c|c|c|c|}
\hline \multicolumn{9}{|c|}{ Dependent variable: $\log$ bilateral imports } \\
\hline & 1 & 2 & 3 & 4 & 5 & 6 & 7 & 8 \\
\hline Controls on trade payments & $-0.549(0.20)$ & & & $-0.476(0.21)$ & $-0.315(0.14)$ & & & $-0.183(0.15)$ \\
\hline Controls on capital transactions & & $-0.148(0.15)$ & & $-0.053(0.16)$ & & $-0.041(0.10)$ & & $0.066(0.10)$ \\
\hline Controls on FX transactions & & & $-0.438(0.25)$ & $-0.228(0.26)$ & & & $-0.607(0.18)$ & $-0.567(0.19)$ \\
\hline Tariff & $-0.725(0.20)$ & $-0.732(0.20)$ & $-0.735(0.20)$ & $-0.727(0.20)$ & $-0.902(0.13)$ & $-0.909(0.13)$ & $-0.923(0.13)$ & $-0.915(0.13)$ \\
\hline Non-tariff barrier index & $-0.205(0.06)$ & $-0.218(0.06)$ & $-0.21(0.06)$ & $-0.206(0.06)$ & $-0.165(0.04)$ & $-0.17(0.04)$ & $-0.166(0.04)$ & $-0.162(0.04)$ \\
\hline Log GDP importer & $1.234(0.23)$ & $1.217(0.24)$ & $1.148(0.24)$ & $1.194(0.24)$ & $1.746(0.15)$ & $1.736(0.15)$ & $1.617(0.16)$ & $1.631(0.16)$ \\
\hline Log GDP exporter & $0.272(0.26)$ & $0.267(0.26)$ & $0.27(0.26)$ & $0.27(0.26)$ & $0.288(0.16)$ & $0.287(0.16)$ & $0.267(0.16)$ & $0.269(0.16)$ \\
\hline Log distance & $-1.807(0.05)$ & $-1.808(0.05)$ & $-1.808(0.05)$ & $-1.807(0.05)$ & & & & \\
\hline Border & $0.552(0.18)$ & $0.552(0.18)$ & $0.552(0.18)$ & $0.553(0.18)$ & & & & \\
\hline Ever colony & $1.02(0.52)$ & $1.023(0.52)$ & $1.02(0.52)$ & $1.023(0.52)$ & & & & \\
\hline Common language & $0.903(0.07)$ & $0.901(0.07)$ & $0.902(0.07)$ & $0.901(0.07)$ & & & & \\
\hline $\begin{array}{l}\text { Importer WTO member, } \\
\text { exporter not }\end{array}$ & $-0.086(0.11)$ & $-0.103(0.11)$ & $-0.092(0.11)$ & $-0.078(0.11)$ & $0.205(0.08)$ & $0.194(0.08)$ & $0.217(0.08)$ & $0.22(0.08)$ \\
\hline Both countries WTO member & $0.413(0.08)$ & $0.397(0.08)$ & $0.406(0.08)$ & $0.42(0.08)$ & $0.24(0.07)$ & $0.23(0.07)$ & $0.24(0.07)$ & $0.243(0.07)$ \\
\hline $\begin{array}{l}\text { HMR predicted } \\
\text { probability of non-zero trade }\end{array}$ & $8.135(0.86)$ & $8.08(0.87)$ & $8.131(0.86)$ & $8.088(0.87)$ & $2.709(2.37)$ & $2.733(2.37)$ & $2.835(2.37)$ & $2.809(2.37)$ \\
\hline $\begin{array}{l}\text { Mills ratio } \\
\text { for non-zero trade }\end{array}$ & $5.417(0.51)$ & $5.383(0.51)$ & $5.416(0.51)$ & $5.385(0.51)$ & $0.209(1.47)$ & $0.223(1.47)$ & $0.152(1.47)$ & $0.149(1.47)$ \\
\hline $\begin{array}{l}\text { Import country } \\
\text { fixed effect }\end{array}$ & Yes & Yes & Yes & Yes & No & No & No & No \\
\hline $\begin{array}{l}\text { Export country } \\
\text { fixed effect }\end{array}$ & Yes & Yes & Yes & Yes & No & No & No & No \\
\hline Country-pair fixed effect & No & No & No & No & Yes & Yes & Yes & Yes \\
\hline Year fixed effect & Yes & Yes & Yes & Yes & Yes & Yes & Yes & Yes \\
\hline Observations & 30411 & 30397 & 30411 & 30397 & 30411 & 30397 & 30411 & 30397 \\
\hline$R^{2}$ & 0.66 & 0.66 & 0.66 & 0.66 & 0.02 & 0.02 & 0.03 & 0.03 \\
\hline
\end{tabular}

Note: Robust standard errors, clustered by importers, are in parentheses. 
controls on trade payments remain significant. The point estimate for controls on trade payments is -0.476 , slightly less than the corresponding one in the benchmark regression. Columns 5-8 are regressions with country-pair fixed effects. Controls on trade payments have a negative coefficient which is significant only when included by itself. With all three controls in the same regression, controls on FX transactions remain negative and significant.

\subsection{Additional control variables}

We have considered additional control variables. The most important ones are corruption and trade openness. The results are reported in Table 5. All regressions include country-pair fixed effects and year fixed effects. Since the level of corruption is a slow-moving variable, its direct effect is likely captured by the country fixed effects. In columns $1-4$ of the table, we look at the interaction between corruption and the exchange controls. Specifically, we create a dummy for "more corrupt countries" if their corruption rating - based on the World Bank Institute's "Control of Corruption" index - exceeds the median in the sample. In addition to the three exchange controls, we then add the interaction terms between each of the exchange control measure and the corruption dummy. The results in columns $1-4$ provide some weak evidence that exchange controls have a reduced negative effect on trade in relatively more corrupt economies. This suggests that corruption may make evasion of exchange control a bit easier on average.

Trade openness itself may alter the effect of a given level of exchange controls on trade. A very high volume of trade opens up many channels to evade exchange controls through misinvoicing of trade. If customs inspection per unit of trade declines with the volume of trade, then the negative effect of exchange controls on trade may also decline. ${ }^{3}$ To examine this, we create a dummy for "more open economies" for countries whose trade-to-GDP ratio exceeds the median value. The dummy is interacted with the three exchange controls. The results are reported in columns 5-8 of Table 5. The interaction terms have generally positive signs (with one exception). This is consistent with the notion that exchange controls have a smaller negative effect on trade in more open economies.

\subsection{Finer classification of exchange controls}

As the restriction indices are based on many indicators for different dimensions of the controls, a question of interest is which sub-categories of controls have greater adverse effects. To answer it, we break down the three indices further into finer sub-categories. The controls on trade payments are divided into controls over imports and those over exports. Note controls on exports can have a negative effect on imports and vice versa due to the Lerner symmetry theorem. The controls on capital transactions are broken down to eight sub-categories that cover controls on capital and money market instruments, derivatives, FDI, credit operations (loans), real estates, commercial banks, institutional investors, and personal capital transactions. The controls on FX transactions are sub-divided into exchange taxes, exchange subsidies, controls on forward markets, administrative controls, controls on setting up bank accounts,

\footnotetext{
${ }^{3}$ Aizenman (2003) proposes a model in which domestic financial repression leads to incentive for capital flight. Trade openness facilitates capital flight precisely because of the difficulty in enforcing exchange controls when trade volume is big.
} 
Table 5

Additional controls: corruption and trade openness

\begin{tabular}{|c|c|c|c|c|c|c|c|c|}
\hline \multicolumn{9}{|c|}{ Dependent variable: log bilateral imports } \\
\hline & 1 & 2 & 3 & 4 & 5 & 6 & 7 & 8 \\
\hline $\begin{array}{l}\text { Controls on trade } \\
\text { payments }\end{array}$ & $-0.448(0.108)$ & & & $-0.063(0.131)$ & $-0.606(0.121)$ & & & $-0.418(0.154)$ \\
\hline $\begin{array}{l}\text { Controls on capital } \\
\text { transactions }\end{array}$ & & $-0.05(0.072)$ & & $0.05(0.082)$ & & $-0.054(0.072)$ & & $0.182(0.085)$ \\
\hline $\begin{array}{l}\text { Controls on FX } \\
\text { transactions }\end{array}$ & & & $-0.56(0.122)$ & $-0.689(0.144)$ & & & $-0.47(0.116)$ & $-0.469(0.134)$ \\
\hline $\begin{array}{l}\text { Controls on trade } \\
\text { payments in more } \\
\text { corrupt countries }\end{array}$ & $0.026(0.059)$ & & & $-0.571(0.139)$ & & & & \\
\hline $\begin{array}{l}\text { Controls on capital } \\
\text { transactions in less } \\
\text { corrupt countries }\end{array}$ & & $0.061(0.036)$ & & $0.05(0.093)$ & & & & \\
\hline $\begin{array}{l}\text { Controls on FX } \\
\text { transactions } \\
\text { in more corrupt } \\
\text { countries }\end{array}$ & & & $0.149(0.048)$ & $0.495(0.122)$ & & & & \\
\hline $\begin{array}{l}\text { Controls on trade } \\
\text { payments in more } \\
\text { open countries }\end{array}$ & & & & & $0.235(0.086)$ & & & $0.004(0.161)$ \\
\hline $\begin{array}{l}\text { Controls on capital } \\
\text { transactions in } \\
\text { more open countries }\end{array}$ & & & & & & $0.092(0.048)$ & & $-0.186(0.097)$ \\
\hline $\begin{array}{l}\text { Controls on FX } \\
\text { transactions in } \\
\text { more open countries }\end{array}$ & & & & & & & $0.218(0.068)$ & $0.463(0.130)$ \\
\hline Tariff & $-0.773(0.107)$ & $-0.782(0.107)$ & $-0.797(0.107)$ & $-0.781(0.107)$ & $-0.787(0.107)$ & $-0.788(0.107)$ & $-0.82(0.107)$ & $-0.814(0.107)$ \\
\hline Non-tariff barrier index & $-0.18(0.034)$ & $-0.186(0.034)$ & $-0.176(0.034)$ & $-0.171(0.034)$ & $-0.178(0.034)$ & $-0.189(0.034)$ & $-0.186(0.034)$ & $-0.177(0.034)$ \\
\hline Log GDP importer & $1.233(0.099)$ & $1.218(0.099)$ & $1.154(0.101)$ & $1.174(0.102)$ & $1.209(0.099)$ & $1.199(0.099)$ & $1.113(0.101)$ & $1.132(0.102)$ \\
\hline Log GDP exporter & $0.865(0.091)$ & $0.86(0.091)$ & $0.848(0.091)$ & $0.863(0.092)$ & $0.86(0.091)$ & $0.856(0.091)$ & $0.842(0.091)$ & $0.85(0.092)$ \\
\hline Importer WTO member, & $0.248(0.056)$ & $0.229(0.056)$ & $0.235(0.056)$ & $0.237(0.056)$ & $0.251(0.055)$ & $0.237(0.055)$ & $0.247(0.056)$ & $0.248(0.056)$ \\
\hline
\end{tabular}

exporter not

$0.248(0.056)$

(continued on next page) 
Table 5 (continued)

Dependent variable: $\log$ bilateral imports

\begin{tabular}{|c|c|c|c|c|c|c|c|c|}
\hline & 1 & 2 & 3 & 4 & 5 & 6 & 7 & 8 \\
\hline $\begin{array}{l}\text { Both countries WTO } \\
\text { member }\end{array}$ & $0.356(0.049)$ & $0.336(0.049)$ & $0.337(0.049)$ & $0.343(0.049)$ & $0.357(0.049)$ & $0.343(0.049)$ & $0.347(0.049)$ & $0.352(0.049)$ \\
\hline $\begin{array}{l}\text { HMR predicted probability of } \\
\text { non-zero trade }\end{array}$ & $-0.56(1.958)$ & $-0.495(1.958)$ & $-0.447(1.958)$ & $-0.493(1.957)$ & $-0.529(1.958)$ & $-0.507(1.958)$ & $-0.428(1.958)$ & $-0.467(1.958)$ \\
\hline Mills ratio for non-zero trade & $-0.994(1.240)$ & $-0.972(1.241)$ & $-1.026(1.240)$ & $-0.97(1.240)$ & $-1.006(1.240)$ & $-1.003(1.241)$ & $-1.043(1.240)$ & $-1.023(1.240)$ \\
\hline Country-pair fixed effect & Yes & Yes & Yes & Yes & Yes & Yes & Yes & Yes \\
\hline Year fixed effect & Yes & Yes & Yes & Yes & Yes & Yes & Yes & Yes \\
\hline Observations & 58098 & 58065 & 58098 & 58065 & 58098 & 58065 & 58098 & 58065 \\
\hline$R^{2}$ & 0.02 & 0.02 & 0.02 & 0.02 & 0.02 & 0.02 & 0.02 & 0.02 \\
\hline
\end{tabular}

Note: $R^{2}$ do not account for the explanatory power of the country-pair fixed effects. 
Table 6

Finer classification of exchange controls

\begin{tabular}{|c|c|c|c|c|c|c|c|c|}
\hline & 1 & 2 & 3 & 4 & 5 & 6 & 7 & 8 \\
\hline Tariff & $-0.729(0.196)$ & $-0.727(0.204)$ & $-1.052(0.211)$ & $-1.145(0.245)$ & $-0.764(0.111)$ & $-0.767(0.119)$ & $-0.909(0.124)$ & $-0.867(0.141)$ \\
\hline Non-tariff barrier index & $-0.197(0.048)$ & $-0.197(0.054)$ & $-0.194(0.050)$ & $-0.189(0.053)$ & $-0.179(0.034)$ & $-0.161(0.039)$ & $-0.154(0.040)$ & $-0.173(0.045)$ \\
\hline Multiple exchange rates & $0.019(0.046)$ & $-0.014(0.051)$ & $-0.02(0.050)$ & $-0.083(0.052)$ & $0.088(0.031)$ & $0.062(0.036)$ & $0.082(0.034)$ & $0.025(0.039)$ \\
\hline $\begin{array}{l}\text { Controls related } \\
\text { to exports }\end{array}$ & $-0.518(0.117)$ & & & $-0.471(0.208)$ & $-0.493(0.077)$ & & & $-0.443(0.160)$ \\
\hline $\begin{array}{l}\text { Controls related } \\
\text { to imports }\end{array}$ & $-0.468(0.131)$ & & & $-0.298(0.261)$ & $-0.348(0.094)$ & & & $-0.118(0.183)$ \\
\hline Exchange taxes & & $-0.148(0.077)$ & & $-0.049(0.095)$ & & $0.006(0.060)$ & & $0.046(0.079)$ \\
\hline Exchange subsidies & & $-0.16(0.072)$ & & $-0.153(0.092)$ & & $-0.18(0.048)$ & & $-0.119(0.065)$ \\
\hline $\begin{array}{l}\text { Absence of currency } \\
\text { forward markets }\end{array}$ & & $0.025(0.048)$ & & $0.031(0.049)$ & & $0.009(0.038)$ & & $-0.003(0.039)$ \\
\hline Administrative control & & $-0.041(0.056)$ & & $-0.019(0.059)$ & & $0.001(0.047)$ & & $-0.023(0.049)$ \\
\hline $\begin{array}{l}\text { Restrictions on opening } \\
\text { domestic/FX bank } \\
\text { accounts }\end{array}$ & & $-0.055(0.079)$ & & $-0.048(0.089)$ & & $-0.106(0.064)$ & & $-0.103(0.075)$ \\
\hline $\begin{array}{l}\text { Arrears unsettled } \\
\text { due to lack } \\
\text { of FX }\end{array}$ & & $-0.299(0.071)$ & & $-0.21(0.082)$ & & $-0.46(0.046)$ & & $-0.317(0.063)$ \\
\hline $\begin{array}{l}\text { Selling/buying gold } \\
\text { and banknotes }\end{array}$ & & $0.107(0.051)$ & & $0.118(0.052)$ & & $0.1(0.037)$ & & $0.08(0.040)$ \\
\hline $\begin{array}{l}\text { Currency requirements } \\
\text { for pricing/settlement/etc. }\end{array}$ & & $-0.078(0.033)$ & & $-0.086(0.036)$ & & $-0.059(0.024)$ & & $-0.068(0.027)$ \\
\hline $\begin{array}{l}\text { Payments/proceeds for } \\
\text { invisible } \\
\text { transactions \& transfers }\end{array}$ & & $0.136(0.129)$ & & $0.549(0.161)$ & & $0.163(0.092)$ & & $0.287(0.119)$ \\
\hline $\begin{array}{l}\text { Transactions on capital \& } \\
\text { money } \\
\text { market instruments }\end{array}$ & & & $-0.187(0.064)$ & $-0.199(0.068)$ & & & $-0.052(0.050)$ & $-0.059(0.053)$ \\
\hline Controls on credit operations & & & $0.044(0.060)$ & $-0.042(0.072)$ & & & $0.06(0.048)$ & $0.026(0.058)$ \\
\hline $\begin{array}{l}\text { Controls on derivatives } \\
\text { transactions }\end{array}$ & & & $-0.147(0.055)$ & $-0.059(0.059)$ & & & $-0.113(0.045)$ & $-0.047(0.050)$ \\
\hline Controls on real & & & $-0.065(0.051)$ & $-0.069(0.055)$ & & & $-0.068(0.039)$ & $-0.058(0.043)$ \\
\hline
\end{tabular}


Table 6 (continued)

\begin{tabular}{|c|c|c|c|c|c|c|c|c|}
\hline & 1 & 2 & 3 & 4 & 5 & 6 & 7 & 8 \\
\hline Controls on FDI & & & $0.114(0.041)$ & $0.163(0.041)$ & & & $0.041(0.032)$ & $0.081(0.035)$ \\
\hline $\begin{array}{l}\text { Restrictions on institutional } \\
\text { investors }\end{array}$ & & & $0.121(0.042)$ & $0.1(0.047)$ & & & $0.076(0.032)$ & $0.058(0.036)$ \\
\hline $\begin{array}{l}\text { Controls on personal } \\
\text { capital transactions }\end{array}$ & & & $0.106(0.059)$ & $0.155(0.073)$ & & & $0.135(0.039)$ & $0.195(0.055)$ \\
\hline Observations & 57621 & 51964 & 46925 & 43411 & 57621 & 51964 & 46925 & 43411 \\
\hline$R^{2}$ & 0.76 & 0.76 & 0.77 & 0.77 & 0.02 & 0.02 & 0.02 & 0.02 \\
\hline
\end{tabular}

Notes: 1/Regressions 1-3 have country fixed effects, and regressions 4-6 have country-pair fixed effects. All other regressors in Table 2 are also included but not reported. $2 / R^{2}$ in the last three columns do not account for the explanatory power of the country-pair fixed effects. 
controls on current transfers, controls on trade in gold and bank coins, and existence of arrears due to lack of FX.

The regression results are reported in Table 6. As in the benchmark case, we place the controls indices one by one first, and then pool them together. For each model, we implement two variations, one with separate importer and exporter fixed effects, and the other with countrypair fixed effects. Many sub-indices show a negative sign, suggesting a trade-reducing effect. Some sub-categories are significant for all specifications, such as controls on export proceeds, controls on setting up bank accounts, existence of arrears due to lack of FX, and currency requirements for pricing/settlements. It is particularly noteworthy that controls over transactions of capital and money market instruments (including equity and bond investments) have negative and significant signs in the models with importer and exporter fixed effect. One caveat for the regressions with a large number of restriction sub-categories is that some of them are highly correlated with each others, making statistical inference difficult. For example, the average pair-wise correlation among the eight indices for capital transactions is 0.6 . Therefore, the estimates need to be interpreted with caution.

\subsection{A case study of the emerging market experiences in the 1990s}

To supplement the full-sample analysis, we now turn to a case study of the experiences of some emerging market economies that tightened exchange controls during the Asian-Latin American financial crisis of the late 1990s. As the increases in the controls were primarily motivated by a desire to stop capital outflows or otherwise reduce the chance of a speculative attack on their currencies, the changes in the controls were arguably exogenous with respect to the countries' trade flows.

We would like to work with a group of countries for which international capital flows are significant relative to their GDPs (at least prior to the crisis). Therefore, we start with a set of countries that are included in the MSCI emerging market index, and narrow down the list to those developing economies that raised controls on either capital transactions or FX transactions during 1996-1999. We are left with 11 countries (marked by \# in Appendix 2). As it turns out, very few of them significantly altered their tariffs, NTB ratings, or even controls on trade payments during the period. Therefore, on an ex ante basis, we do not have much hope in identifying a significant effect of these three variables. Nonetheless, we hope to identify some effects coming from changes in the controls on capital and FX transactions.

We implement a time-differenced version of Eq. (1), with the change in log bilateral imports from 1996 to 1999 as the dependent variable. Naturally, all variables that are time-invariant are eliminated, including the various fixed effects. Our specification is:

$$
\begin{aligned}
\Delta \log \left(\text { import }_{i, j, t}\right)= & \alpha_{1} \Delta \log \left(\mathrm{GDP}_{i}\right)+\alpha_{2} \Delta \log \left(\mathrm{GDP}_{j}\right)+\Delta \text { Restriction Indices }_{i, t} \gamma \\
& +\delta \Delta \operatorname{Tarrif}_{i, j, t}+\eta \Delta \mathrm{NTB}_{i, t}+\varepsilon_{i, j, t},
\end{aligned}
$$

where $\Delta$ denotes a change in the relevant variable from 1996 to 1999 . The regression result without the NTB variable is reported in the first column of Table 7. The coefficient for the controls on capital transactions is -1.46 and significant at the $5 \%$ level, and that for the controls on FX transactions is -1.28 and significant. As expected, the coefficients on tariff rate and controls on trade payments are not statistically different from zero. Note that a fall in imports due to a contraction of domestic demand is explicitly controlled for since the change in an importer's GDP is a regressor. In the second column, we add change in the NTB ratings as an extra 
Table 7

Emerging market economies during 1996-1999 (countries that increased controls either on capital or FX transactions)

\begin{tabular}{|c|c|c|c|}
\hline \multicolumn{4}{|c|}{ Dependent variable $=$ change in log bilateral imports from 1996 to 1999} \\
\hline & 1 & 2 & 3 \\
\hline $\begin{array}{l}\text { Change in controls } \\
\text { on trade payments }\end{array}$ & $0.456(0.351)$ & $0.396(0.346)$ & $0.240(0.380)$ \\
\hline $\begin{array}{l}\text { Change in controls } \\
\text { on capital transactions }\end{array}$ & $-1.463(0.322)$ & $-1.578(0.529)$ & $-1.364(0.351)$ \\
\hline $\begin{array}{l}\text { Change in controls on FX } \\
\text { transactions }\end{array}$ & $-1.275(0.441)$ & $-1.194(0.396)$ & $-1.394(0.453)$ \\
\hline $\begin{array}{l}\text { Change in log importer's } \\
\text { GDP }\end{array}$ & $0.635(0.243)$ & $0.709(0.271)$ & $0.401(0.360)$ \\
\hline $\begin{array}{l}\text { Change in log exporter's } \\
\text { GDP }\end{array}$ & $1.219(0.432)$ & $1.225(0.434)$ & $1.239(0.425)$ \\
\hline Change in tariff & $0.265(0.162)$ & $0.248(0.189)$ & $0.313(0.201)$ \\
\hline Change in NTB index & & $0.055(0.107)$ & $0.166(0.111)$ \\
\hline $\begin{array}{l}\text { Multilateral real } \\
\text { exchange rate }\end{array}$ & & & $0.250(0.479)$ \\
\hline $\begin{array}{l}\text { Bilateral real } \\
\text { exchange rate }\end{array}$ & & & $0.451(0.242)$ \\
\hline Observations & 1142 & 1142 & 1142 \\
\hline$R^{2}$ & 0.01 & 0.01 & 0.02 \\
\hline
\end{tabular}

regressor and obtain broadly similar results. To account for the effects of exchange rate fluctuations on trade flows, multilateral and bilateral real exchange rates are included in the regression. The results are reported in column 3. The estimates for the exchange controls remain similar to the other regressions. These results suggest that using exchange controls to regulate capital flows can have the (unintended) consequence of harming trade.

\section{Concluding remarks}

This paper sets out to investigate a possible collateral damage of exchange controls, namely their negative effects on international trade. It indeed uncovers economically and statistically significant evidence of the adverse effects. An increase in the controls on foreign exchange transactions by one standard deviation reduces trade by the same amount as an increase in tariff rate by 11 percentage points. An increase in the controls on trade payments has the same negative effect on trade as an increase in tariff rate by 14 percentage points. The experience of the emerging market economies during the late 1990s suggests that controls on capital transactions intended to regulate capital flows also tend to harm trade substantially. The evidence reported in the paper suggests that the collateral damage of exchange controls should be a part of any assessment of the desirability of capital account liberalization (see Kose et al., 2006, for a re-assessment of the effects of financial globalization).

This paper represents a first step in understanding the effects of exchange controls on trade. It is possible that the effects are non-linear: the same measure in an already restrictive exchange control regime may do more harm than in a less restrictive one. The effects may vary by sectors: exchange controls may raise the cost of trading in heterogeneous products more than the cost of trading in homogeneous products. As heterogeneous products have 
a greater variance in their unit values over different varieties, it may be more difficult for traders to convince bureaucrats that a particular transaction is not mis-invoiced to evade exchange controls. In this case, exchange controls imply one more distortion by affecting a country's pattern of specialization. The effects may also interact with other features of an economy: the same exchange controls may do either more or less damage in a governance-challenged economy depending on whether corruption primarily weakens the exchange controls or exacerbates the burden of complying with the controls. These are all fruitful topics for further research.

\section{Acknowledgements}

The authors are affiliated with the Trade and Investment Division of the International Monetary Fund. The authors wish to thank Joshua Aizenman, Jahangir Aziz, Adrienne Cheasty, Robert Feldman, Kristin Forbes, Anne-Marie Gulde-Wolf, Hans Peter Lankes, Nuno Limao, Kristin Forbes, Christian Mulder, Paulo Neuhaus, Alejandro Santos, Natalia Tamirisa, especially Mark Spiegel, other contributors to departmental reviews, and other participants at the JIMF-SCCIE conference at the University of California, Santa Cruz and an IMF seminar for helpful comments, and Erik von Uexkull for capable research assistance. The paper represents the personal views of the authors, and not those of the IMF, its Executive Directors, or Management.

\section{Appendix 1. Exchange controls: source, measurement, and indices}

The exchange control indices are computed by the authors based on the exchange-restriction indicators in the IMF's Annual Report on Exchange Arrangements and Exchange Restrictions (AREAER) database, which in turn is compiled from the annual reporting by the authorities of IMF member countries. The current classification system was first used in 1996 for a subset of countries but soon expanded to cover all member countries. This appendix lists these indicators and explains how the restriction indices are constructed. Formal definitions of these indicators are available in any issue of the AREAER.

Three indices are constructed to gauge the coverage of exchange controls in three groups: trade payments, capital transactions, and FX transactions and other items. Each index is constructed as

$$
\text { Restriction Index } \operatorname{In}_{i, t}=\sum_{j=1}^{n} D_{j, i, t} \times W_{j},
$$

where $D_{i, j, t}$ is a dummy variable that takes the value of 1 if country $i$ has restriction measured by indicator $j$ in year $t$, and $W_{j}$ is the weight assigned to the indicator $j$. The weights are chosen so that the major components within each group receive same weights. For example, the documentation requirements for imports receive the same weight as financing requirements for imports, although there are five sub-indicators for the former and three for the latter. By construction, this index takes the value between 0 and 1 , with a higher value indicating a more restrictive regime. 


\section{Controls on trade payments}

1. Imports and import payments:

1.1. Foreign exchange budget

1.2. Financing requirements for imports

a. Minimum financing requirements; b. Advance payment requirements; c. Advance import deposits

1.3. Documentation requirements for release of foreign exchange for imports

a. Domiciliation requirement; b. Preshipment inspection; c. Letters of credit; d. Import licenses used as exchange licenses; e. Other

1.4. State import monopoly

2. Exports and export proceeds:

2.1. Repatriation requirement

a. Surrender requirement

2.2. Financing requirements

2.3. Documentation requirements

a. Letters of credit; b. Guarantees; c. Domiciliation; d. Preshipment inspection; e. Other

2.4. Export licenses

a. Without quotas; b. With quotas

2.5. Export taxes

a. Collected through the exchange system; b. Other export taxes

Controls on capital transactions

1. Controls on capital and money market instruments (Each category has four indicators: (1) Purchase locally by nonresidents; (2) Sale or issue locally by nonresidents; (3) Purchase abroad by residents; (4) Sale or issue abroad by residents)

1.1. On capital market securities

a. Shares or other securities of a participating nature;

b. Bonds or other debt securities

1.2. On money market instruments

1.3. On collective investment securities

2. Controls on derivatives and other instruments (Including four sub-indicators: (1) Purchase locally by nonresidents; (2) Sale or issue locally by nonresidents; (3) Purchase abroad by residents; (4) Sale or issue abroad by residents)

3. Controls on credit operations (Each has two sub-indicators: (1) By residents to nonresidents; (2) To residents from nonresidents)

3.1. Commercial credits

3.2. Financial credits

3.3. Guarantees, sureties, and financial backup facilities

4. Controls on direct investment

4.1. Outward direct investment

4.2. Inward direct investment

5. Controls on liquidation of direct investment

6. Controls on real estate transactions (Separate indicators for: a. Purchase abroad by residents; b. Purchase locally by nonresidents; c. Sale locally by nonresidents)

7. Controls on personal capital transactions 


\subsection{Loans}

a. By residents to nonresidents, b. To residents from nonresidents

7.2. Gifts, endowments, inheritances, and legacies

a. By residents to nonresidents, b. To residents from nonresidents

7.3. Settlements of debts abroad by immigrants

7.4. Transfer of assets

a. Transfer abroad by emigrants; b. Transfer into the country by immigrants

7.5. Transfer of gambling and prize earnings

8. Provisions specific to commercial banks and other credit institutions

8.1. Borrowing abroad

8.2. Maintenance of accounts abroad

8.3. Lending to nonresidents (financial or commercial credits)

8.4. Lending locally in foreign exchange

8.5. Purchase of locally issued securities denominated in foreign exchange

8.6. Differential treatment of deposit accounts in foreign exchange

a. Reserve requirements; b. Liquid asset requirements; c. Interest rate controls; d. Credit controls.

8.7. Differential treatment of deposit accounts held by nonresidents

a. Reserve requirements; b. Liquid asset requirements; c. Interest rate controls; d. Credit controls.

8.8. Investment regulations

a. Abroad by banks; b. In banks by nonresidents

8.9. Open foreign exchange position limits

a. On resident assets and liabilities; b. On nonresident assets and liabilities

9. Provisions specific to institutional investors

9.1. Limits (max.) on securities issued by nonresidents

9.2. Limits (max.) on investment portfolio held abroad

9.3. Limits (min.) on investment portfolio held locally

9.4. Currency-matching regulations on assets/liabilities composition

10. Other controls imposed by securities laws

Controls on FX transactions and other items

1. Exchange tax

2. Exchange subsidy

3. Forward exchange market

Official cover of forward operations

4. Prescription of currency requirements

4.1. Controls on the use of domestic currency

a. For current transactions and payments; b. For capital transactions

i. Transactions in capital and money market instruments

ii. Transactions in derivatives and other instruments

iii. Credit operations

4.2. Use of foreign exchange among residents

5. Administration of control

6. Payments arrears

6.1. Official

6.2. Private 
7. Controls on trade in gold (coins and/or bullions)

7.1. On domestic ownership and/or trade

7.2. On external trade

8. Controls on exports and imports of banknotes

8.1. On exports

a. Domestic currency; b. Foreign currency

8.2. On imports

a. Domestic currency; b. Foreign currency

9. Controls on the following transfers (Each below has three sub-categories: (1) Prior approval; (2) Quantitative limits; (3) Indicative limits/bona fide test)

9.1. Trade-related payments

9.2. Investment-related payments

9.3. Payments for travel

9.4. Personal payments

9.5. Foreign workers' wages

9.6. Credit card use abroad

9.7. Other payments

10. Proceeds from invisible transactions and current transfers

10.1. Repatriation requirements

Surrender requirements

10.2. Restrictions on use of funds

11. Resident accounts

11.1. Foreign exchange accounts permitted

a. Held domestically (approval required); b. Held abroad (approval required)

11.2. Accounts in domestic currency held abroad

11.3. Accounts in domestic currency convertible into foreign currency

12. Nonresident accounts

12.1. Foreign exchange accounts permitted (approval required)

12.2. Domestic currency accounts

Convertible into foreign currency (approval required)

12.3. Blocked accounts

Appendix 2. List of countries in the sample

\begin{tabular}{llll}
\hline Albania & Denmark & Laos & Rwanda \\
Algeria & Djibouti & Latvia & Saudi Arabia \\
Angola & Dominica & Lebanon & Senegal \\
Antigua and Barbuda & Dominican Republic & Lithuania & Seychelles \\
Argentina & Ecuador & Luxembourg & Singapore \\
Armenia & Egypt & Macedonia & Slovak Republic \\
Australia & El Salvador & Madagascar & Slovenia \\
Azerbaijan & Equatorial Guinea & Malawi & South Africa \\
Bahamas & Estonia & Malaysia\# & Spain \\
Bahrain & Ethiopia & Maldives & Sri Lanka\# \\
Bangladesh & France & Mali & St. Kitts and Nevis \\
Barbados & Gabon & Malta & St. Lucia \\
Belarus & Georgia & Mauritania & St. Vincent and The Grenadines \\
Belgium & Germany & Mauritius & Sudan \\
Belize & Ghana & Mexico & Suriname
\end{tabular}


Appendix 2 (continued)

\begin{tabular}{llll}
\hline Benin & Greece & Moldova & Switzerland \\
Bolivia & Grenada & Morocco\# & Syria \\
Brazil\# & Guatemala & Mozambique & Tanzania \\
Bulgaria & Guinea-Bissau & Nepal & Thailand\# \\
Burkina Faso & Guyana & Netherlands & Togo \\
Burundi & Honduras & New Zealand & Trinidad and Tobago \\
Cambodia & Hong Kong & Nicaragua & Tunisia \\
Cameroon & Hungary & Niger & Turkey\# \\
Canada & Iceland & Nigeria & Turkmenistan \\
Central African Rep & India & Norway & Uganda \\
Chad & Indonesia & Oman & Ukraine \\
Chile & Iran & Pakistan\# & United Kingdom \\
China & Ireland & Panama & United States \\
Colombia & Italy & Papua New Guinea & Uruguay \\
Congo, Democratic Republic of & Jamaica & Paraguay & Uzbekistan \\
Congo, Republic of & Japan & Peru & Venezuela \\
Costa Rica & Jordan & Philippines\# & Vietnam \\
Cote d' Ivoire & Kenya & Poland\# & Yemen \\
Croatia & Korea & Portugal & Zambia \\
Cyprus & Kuwait & Romania & Zimbabwe \\
Czech Republic \# & Kyrgyz Republic & Russian Federation\# & \\
\hline
\end{tabular}

Note: \# denotes countries in the sample used in Table 7.

\section{References}

Aizenman, J., 2003. On the hidden links between financial and trade opening. Working Paper 9906, National Bureau of Economic Research, Cambridge, MA.

Anderson, J., Van Wincoop, E., 2003. Gravity with gravitas: a solution to the border puzzle. American Economic Review 93 (1), 170-192.

Forbes, K. One cost of the Chilean capital controls: increased financial constraints for smaller traded firms. Working Paper No. 4273-02, MIT Sloan School, Journal of International Economics, in press.

Frankel, J., Wei, S., 1994. Yen bloc or dollar bloc: exchange rate policies of the East Asian economies. In: Ito, T., Krueger, A. (Eds.), Macroeconomic Linkages: Savings, Exchange Rates and Capital Flows. University of Chicago Press, Chicago.

Frankel, J., Stein, E., Wei, S., 1997. Regional Trading Blocs in the World Economic System. Institute for International Economics, Washington, DC.

Helpman, E., Melitz, M., Rubinstein, Y., 2005. Trade patterns and trade volume. Working Paper, Harvard University.

International Monetary Fund, 2005. Review of the IMF's Trade Restrictiveness Index. Available from: <http://www. imf.org/external/np/pp/eng/2005/021405r.pdf $>$.

Johnson, S., Kochhar, K., Mitton, T., Tamirisa, N., 2006. Malaysian Capital Controls: Macroeconomics and Institutions. International Monetary Fund. Working Paper No. 06/51.

Kose, A., Prasad, E., Rogoff, K., Wei, S.-J., 2006. Financial globalization: a reappraisal. NBER Working Paper 12484. National Bureau of Economic Research, Cambridge, MA.

Prasad, E., Rogoff, K., Wei, S.-J., Kose, A., 2003. Effects of financial globalization on developing countries: some empirical evidence. Occasional Paper 220, International Monetary Fund.

Rodrik, D., 1998. Who needs capital account convertibility? In: Should the IMF Pursue Capital Account Convertibility? Princeton Essays in International Finance No. 207. International Finance Section, Department of Economics, Princeton University, Princeton, NJ, pp. 55-65.

Rose, A., 2004. Do we really know that the WTO increases trade? American Economic Review 94 (1), $98-114$.

Stiglitz, J., 2002. Globalization and its Discontents. Norton, NY.

Subramanian, A., Wei, S.-J., 2007. The WTO promotes trade, strongly but unevenly. Journal of International Economics $72,151-175$.

Tamirisa, N., 1999. Exchange and capital controls as barriers to trade. IMF Staff Papers 46 (1).

Wei, S.-J., 1996. Intra-national versus international trade: how stubborn are nations in global integration? Working Paper No. 5531 National Bureau of Economic Research, Cambridge, MA. 